\title{
INTRAOPERATIVE ENGINEERING OF OSTEOGENIC GRAFTS COMBINING FRESHLY HARVESTED, HUMAN ADIPOSE-DERIVED CELLS AND PHYSIOLOGICAL DOSES OF BONE MORPHOGENETIC PROTEIN-2
}

Arne Mehrkens $^{1 \S}$, Franziska Saxer ${ }^{1 \S}$, Sinan Güven ${ }^{1}$, Waldemar Hoffmann ${ }^{1}$, Andreas M. Müller ${ }^{1}$, Marcel Jakob ${ }^{1}$, Franz E. Weber ${ }^{2}$, Ivan Martin ${ }^{1 *}$ and Arnaud Scherberich ${ }^{1}$

${ }^{1}$ Departments of Surgery and of Biomedicine, University and University Hospital of Basel, 4031 Basel, Switzerland

${ }^{2}$ Oral Biotechnology \& Bioengineering, Division of Cranio-Maxillo-Facial and Oral Surgery, University Hospital Zürich, 8091 Zürich, Switzerland

${ }^{\S}$ These authors contributed equally to the work acting as co-first authors.

\begin{abstract}
Engineered osteogenic constructs for bone repair typically involve complex and costly processes for cell expansion. Adipose tissue includes mesenchymal precursors in large amounts, in principle allowing for an intraoperative production of osteogenic grafts and their immediate implantation. However, stromal vascular fraction (SVF) cells from adipose tissue were reported to require a molecular trigger to differentiate into functional osteoblasts. The present study tested whether physiological doses of recombinant human BMP-2 (rhBMP-2) could induce freshly harvested human SVF cells to generate ectopic bone tissue. Enzymatically dissociated SVF cells from 7 healthy donors $\left(1 \times 10^{6}\right.$ or $\left.4 \times 10^{6}\right)$ were immediately embedded in a fibrin gel with or without 250 ng rhBMP-2, mixed with porous silicated calciumphosphate granules (Actifuse ${ }^{\circledR}$, Apatech) (final construct size: $0.1 \mathrm{~cm}^{3}$ ) and implanted ectopically for eight weeks in nude mice. In the presence of rhBMP-2, SVF cells not only supported but directly contributed to the formation of bone ossicles, which were not observed in control cell-free, rhBMP-2 loaded implants. In vitro analysis indicated that rhBMP-2 did not involve an increase in the percentage of SVF cells recruited to the osteogenic lineage, but rather induced a stimulation of the osteoblastic differentiation of the committed progenitors. These findings confirm the feasibility of generating fully osteogenic grafts using an easily accessible autologous cell source and low amounts of rhBMP-2, in a timing compatible with an intraoperative schedule. The study warrants further investigation at an orthotopic site of implantation, where the delivery of rhBMP-2 could be bypassed thanks to the properties of the local milieu.
\end{abstract}

Keywords: Bone repair; stem cells; adipose tissue; osteogenesis; tissue engineering.

*Address for correspondence:

Prof. Ivan Martin

Institute for Surgical Research \& Hospital Management University Hospital Basel

Hebelstrasse 20, ZLF, Room 405

4031 Basel, Switzerland

Telephone Number: +41616252384

FAX Number: +41612653990

E-mail: IMartin@uhbs.ch

\section{Introduction}

The standard of care in the treatment of bone defects in orthopaedic, trauma or reconstructive surgery is the transplantation of autologous bone grafts. Alternative options are the implantation of allografts or osteoconductive materials, the local treatment with osteoinductive growth factors such as BMP-2 or BMP-7, or combinations thereof (Berner et al., 2011; De et al., 2007; Saxer F et al., 2010). The engineering of osteogenic bone graft substitutes based on osteoconductive scaffolds combined with autologous osteoprogenitors (mesenchymal stromal cells, MSC) as a biologically active component could provide an attractive alternative, but its translation into clinical practice has proven to be highly challenging (Berner et al., 2011; Cuomo et al., 2009; Evans et al., 2007). Low MSC numbers found in the bone marrow generally require a step of cell expansion for graft manufacturing. This not only is known to be associated with a progressive loss of osteogenic differentiation capacity (Banfi et al., 2000), but also requires processing under costly and tightly regulated Good Manufacturing Practice (GMP) conditions. Thus, cost-effectiveness of the classical bone tissue engineering paradigm still needs to be verified (Meijer et al., 2007).

One possible solution proposed to overcome the limitations above is based on the 3D expansion of MSC directly within porous scaffolds (Braccini et al., 2005). This was shown to reduce intra-individual differences, increase quality of grafts and streamline manufacturing in perfusion bioreactors, with the potential to introduce automation and thus reduce costs (Martin et al., 2009). Another approach has more radically addressed the problem, by trying to eliminate the expansion phase, i.e. reducing the manufacturing process to a one-step surgical procedure. Such an intra-operative approach poses the essential requirements to identify an autologous source of cells that have (i) intrinsic osteogenic capacities in vivo without prior culture or osteoinduction and (ii) are available in sufficient numbers directly upon isolation. Freshly isolated bone marrow-derived cells, possibly harvested using a reamer-irrigator-aspirator (Cox et al., 2011; Stafford and Norris, 2010), concentrated by immunoselection (Aslan et al., 2006) or modified genetically (Evans et al., 2007), have been proposed to be directly used for bone repair. Despite the promising data collected so far, the reproducible collection of a sufficient number of MSC across different patients remains to be demonstrated. The freshly-isolated stromal vascular fraction (SVF) of human 
adipose tissue represents a possibly better cell source for a one-step surgical procedure, given its up to 500-fold larger number of clonogenic progenitors per volume of tissue sample compared to human bone marrow (Fraser et al., 2006; Scherberich et al., 2007). Two studies (Helder et al., 2007; Vergroesen et al., 2011) tested bone formation by autologous SVF cells, intraoperatively processed to generate grafts implanted in a goat spinal fusion model. Those studies demonstrated a superior bone healing when implants were loaded with SVF cells, but the model was not designed to assess the direct osteogenic properties of the SVF-based grafts. Our group recently demonstrated that ectopic implantation in nude mice of human SVF cells seeded on porous hydroxyapatite scaffolds results in the formation of human origin blood vessels and dense osteoid matrix, but no 'frank' bone formation (Müller et al., 2010). These findings suggested that, in the absence of in vitro commitment, additional cues (e.g. osteoinductive factors) might be needed to support ectopic bone tissue generation in vivo.

In the present study, recombinant human bone morphogenetic protein-2 (rhBMP-2) was therefore used as an osteoinductive stimulus (Chen et al., 2004; Jeon et al., 2008) for the implanted SVF cells, at doses known to be insufficient to induce by themselves bone tissue formation (Fujimura et al., 1995). RhBMP-2 was introduced in fibrinceramic-based constructs simultaneously with the freshlyisolated/SVF cells and immediately implanted ectopically in nude mice. Bone formation and the contribution of SVF cells to this process were studied 8 weeks after implantation. In vitro experiments were also performed to address whether rhBMP-2 enhances SVF cell osteogenic differentiation and/or the osteogenic recruitment of clonogenic SVF populations.

\section{Material and Methods}

\section{Cell isolation}

Adipose tissue, in the form of liposuction or excised fat samples, was obtained from 7 healthy female donors following informed consent and according to a protocol approved by the local ethical committee (EKBB, Ref. $78 / 07)$. Minced tissue from excised fat samples or lipoaspirates were processed as previously described (Güven et al., 2011; Müller et al., 2010) and the cell pellets resuspended in complete medium (CM), consisting of $\alpha$-MEM supplemented with $10 \%$ of foetal bovine serum (FBS), $1 \%$ HEPES, $1 \%$ sodium pyruvate and $1 \%$ Penicillin-Streptomycin Glutamate (100x) solution (all from Gibco, www.invitrogen.com).

\section{Cell characterisation}

Fluorescence activated cell sorting (FACS)

SVF cells were analysed by cytofluorimetry with antibodies to CD105, CD90 and CD73 (mesenchymal markers), CD31 and CD34 (endothelial markers), the monocytic marker CD14 and the pan-haematopoietic marker CD45 (antiCD105 antibody from AbD Serotec, www.abdserotec. com, all others from Becton Dickinson Bioscience, www. bdbiosciences.com), as previously described (Gronthos et al., 2001; Güven et al., 2011).

\section{Frequency of clonogenic cells}

The ratio of colony forming unit-osteoblasts (CFU-o) to the total number of formed colonies (colony forming unit-fibroblasts, CFU-f) (Friedenstein et al., 1970; Baksh et al., 2003) was determined by plating $100 \mathrm{SVF}$ cells/well into six well plates. Cells were cultured with $\mathrm{CM}$ or osteogenic medium (OM), consisting of $\mathrm{CM}$ supplemented with $100 \mathrm{nM}$ dexamethasone, $10 \mathrm{mM}$ betaglycerophosphate, and $0.05 \mathrm{mM}$ ascorbic-acid-2-phosphate (Sigma-Aldrich, www.sigmaaldrich.com) for $14 \mathrm{~d}$, in the presence or absence of the indicated concentration of rhBMP-2 (produced in CHO cells by R\&D Systems, www. rndsystems.com). CFU-o were defined as colonies stained positive for alkaline phosphatase (ALP) activity, using a commercially available kit (104-LL kit, Sigma-Aldrich). The CFU-o/CFU-f ratio was determined following counter staining with buffered neutral red solution (N6264, SigmaAldrich), which allowed counting of the total number of CFU-f.

\section{In vitro stimulation with rhBMP-2}

SVF cells were plated on tissue culture plastic and grown to confluence in the presence of CM. Cells were then cultured for $14 \mathrm{~d}$ with either $\mathrm{CM}$ or OM, alone or further supplemented with either 50 or $500 \mathrm{ng} / \mathrm{mL}$ rhBMP-2 (produced in bacteria as previously described (Weber et al., 2002), hereafter referred to as own-produced, or produced in mammalian CHO cells by R\&D Systems) and analysed by reverse transcriptase real time polymerase chain reaction (RT-rt-PCR). Cells were then treated with lysis buffer (Qiagen, http://www.qiagen.com) enriched with 1/100 (V/V) $\beta$-mercaptoethanol (Sigma-Aldrich). RNA was extracted by using a NucleoSpin ${ }^{\circledR}$ RNA II kit (MachereyNagel, http://www.mn-net.com). The RNA was eluted in RNase-free water and transcription into cDNA was performed as previously described (Barbero et al., 2003). The samples were analysed by using a GeneAmp ${ }^{\circledR}$ PCR System 9600 (Perkin Elmer, www.perkinelmer.com) and the transcription levels of osteopontin (OP) and osteocalcin (OC) quantified, with glyceraldehyde 3-phosphate dehydrogenase (GAPDH) as reference housekeeping gene (Frank et al., 2002). SVF cells were similarly plated on tissue culture plastic, grown to confluence and cultured for $7 \mathrm{~d}$ with CM, alone or further supplemented with $500 \mathrm{ng} /$ mL BMP-2 (R\&D Systems). Cells were then detached with trypsin (Invitrogen) and analysed by cytofluorimetry with fluorochrome-conjugated antibodies to ALP and OC (both from R\&D systems, www.rndsystems.com).

\section{Generation and assessment of SVF cells-fibrin- ceramic constructs}

One or four millions SVF cells were suspended in the fibrinogen phase $(30 \mu \mathrm{L})$ of a polymerising fibrin gel (Tisseel ${ }^{\circledR}$, Baxter, www.baxter.com), as described previously (Bensaid et al., 2003; Müller et al., 2010), with or without addition of $250 \mathrm{ng}$ of rhBMP-2 (own-produced or from R\&D Systems). Briefly, following mix with the 

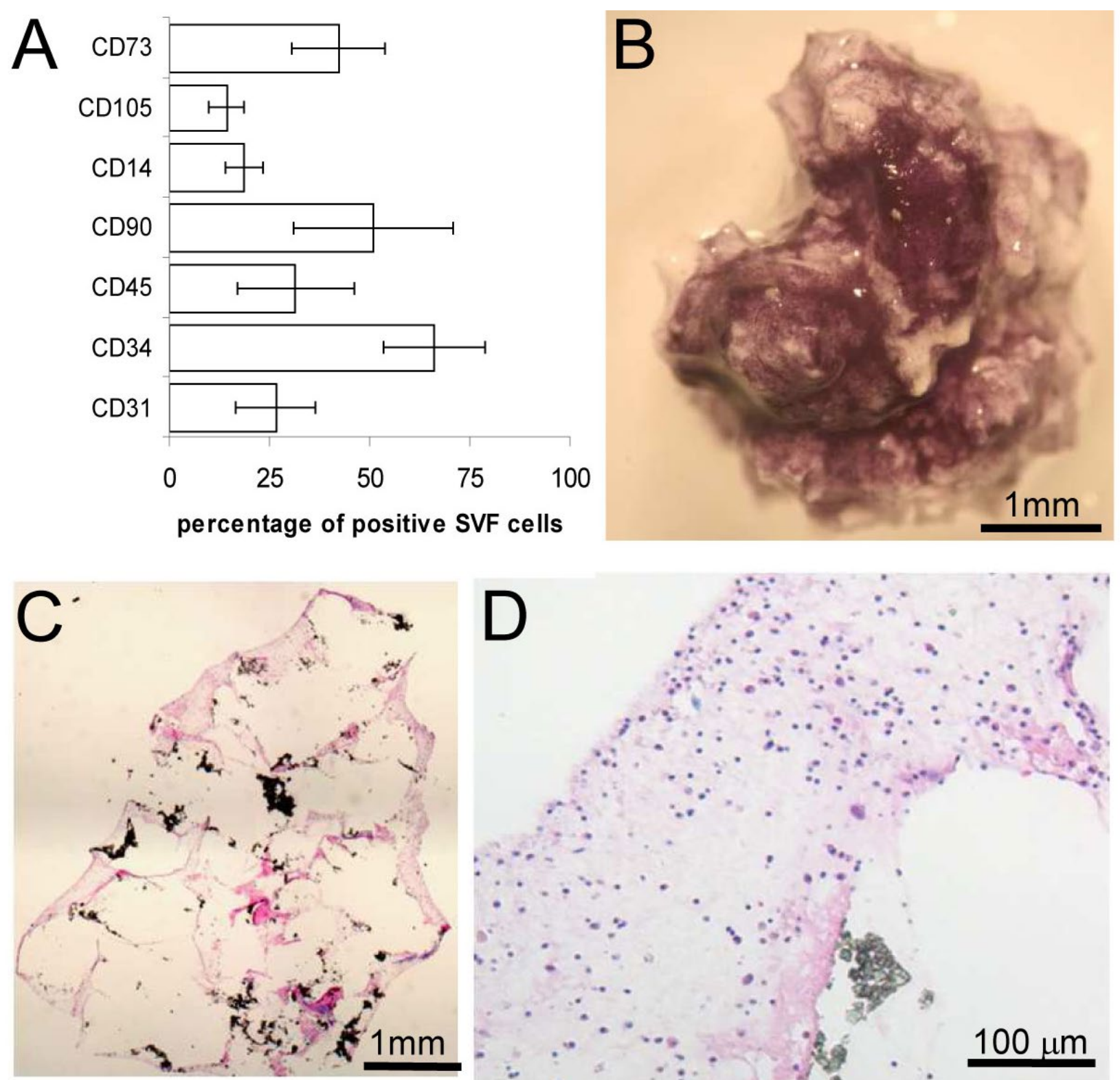

Fig. 1. Characterisation of cells and constructs in vitro. (A) Cytofluorimetric analysis of freshly-isolated SVF cells derived from 7 donors. For every CD marker, the average percentage of cells positive for the marker is plotted. Error bars represent standard deviations. (B) Representative picture of a tetrazolium-based metabolic staining (MTT assay) performed on SVF cells-fibrin gel-ceramic granules constructs to demonstrate the distribution of viable cells. (C and D) Macroscopic (C) and microscopic (D) pictures of haematoxylin/eosin staining performed on histological sections of decalcified, paraffin-embedded samples.

thrombin phase $(30 \mu \mathrm{L})$, the solution was poured onto a volume of approx. $0.06 \mathrm{~cm}^{3}$ of hydroxyapatite granulates of 1-2 mm size (Actifuse ${ }^{\circledR}$ ABX, ApaTech, www.apatech. com) pre-stacked in the wells of a 96-well plate. After 1-2 min, when the gels polymerised, the volume of the final constructs was $0.1 \mathrm{~cm}^{3}$. Those constructs were covered with $\mathrm{CM}$ and transferred into a humidified incubator $\left(37^{\circ} \mathrm{C}, 5 \%\right.$ $\mathrm{CO}_{2}$ ) for $10 \mathrm{~min}$. Directly after fabrication, some constructs were incubated for $2 \mathrm{~h}$ at $37^{\circ} \mathrm{C}$ in a 3-(4,5-dimethylthiazol2-yl)-2,5-diphenyltetrazolium bromide (MTT, SigmaAldrich) solution at a final concentration of $0.05 \mathrm{mg} /$ $\mathrm{mL}$ and the distribution of the blue/purple metabolised substrate of MTT was inspected macroscopically to assess cell viability. Other constructs were fixed overnight in $4 \%$ formalin, paraffin-embedded, sectioned and stained with haematoxylin/eosin (H\&E) for qualitative assessment of the spatial distribution of the seeded cells. The remaining constructs were implanted in nude mice as described below.

\section{In vivo implantation in nude mice and explant analysis}

The maintenance, surgical treatment and sacrifice of animals were performed in accordance with the guidelines of the local veterinary agency ("Kantonales Veterinäramt Basel-Stadt", permission \#1797). Constructs were implanted in the subcutaneous tissue of nude athymic mice (CD1 nu/nu, Charles River, www.criver.com) and harvested after eight weeks following mouse sacrifice 


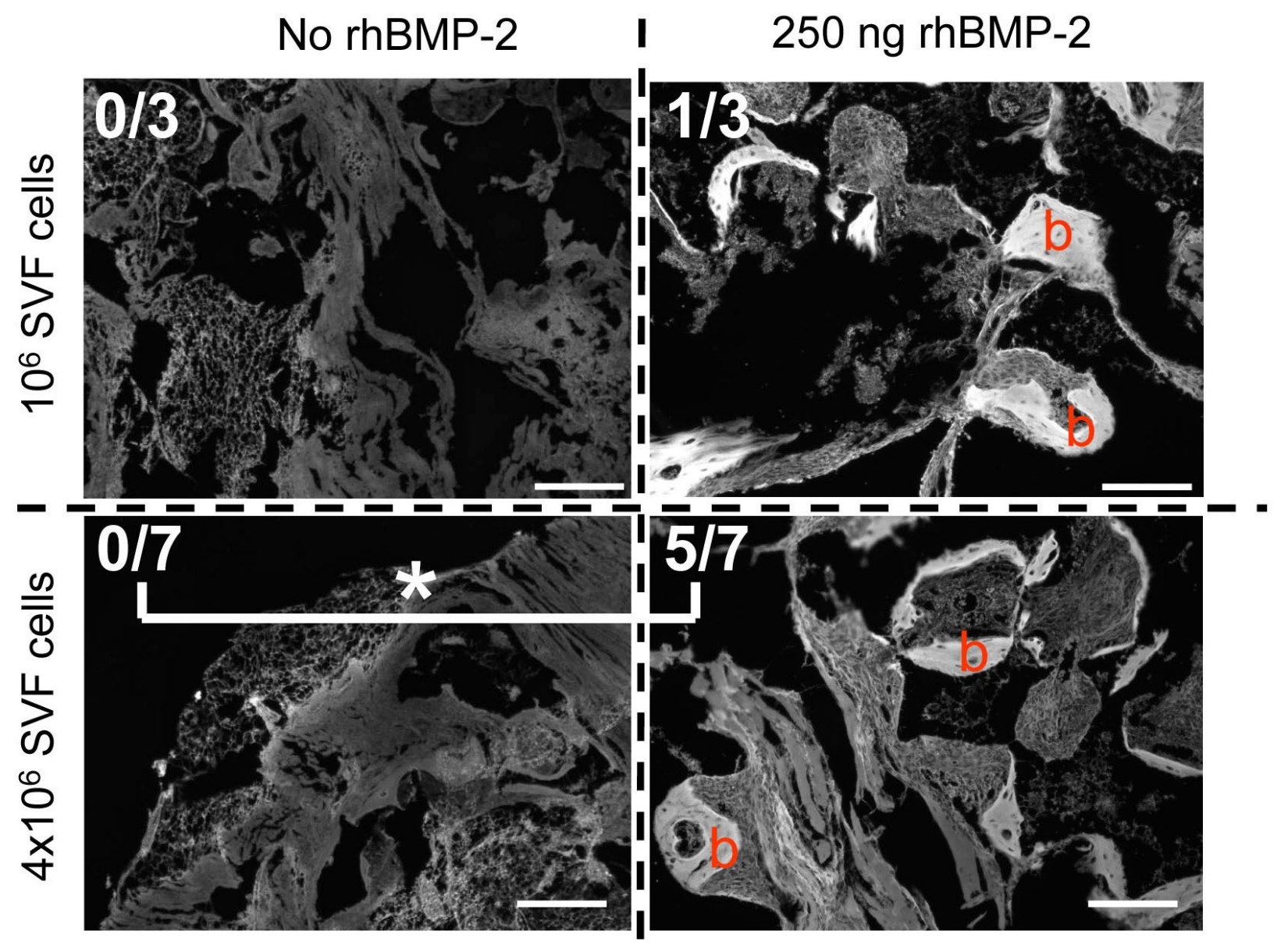

Fig. 2. Comparison of in vivo bone formation. Representative fluorescence microscopy pictures of histology sections of explanted, fixed and decalcified constructs. Experimental conditions are indicated in the figure. The values provided for each experimental condition is the ratio of donors exhibiting bone formation in vivo by the total number of donors tested. Scale bars represent $200 \mu \mathrm{m}$ and (b) indicates bone tissue. * indicates a significant difference $(p<0.05)$ in bone formation as tested by Kruskal-Wallis test followed by post-hoc Dunn's tests.

by inhalation of $\mathrm{CO}_{2}$. Tissues were fixed in $4 \%$ formalin overnight, subjected to slow decalcification in $7 \% \mathrm{w} / \mathrm{v}$ EDTA and $10 \% \mathrm{w} / \mathrm{v}$ sucrose (both from Sigma-Aldrich) at $37{ }^{\circ} \mathrm{C}$ on an orbital shaker for 7-10 d and paraffinembedded. Samples were then cross-sectioned (12 $\mu \mathrm{m}$ thickness) and processed for histological, histochemical and immunohistochemical stainings as follows. Standard H\&E staining and Masson's trichrome staining (Kit Trichrome de Masson-Vert lumière, Réactifs RAL, www.ral-diagnostics.fr) were performed to identify bone tissue formation and maturation stage. Safranin-O staining allowed investigating the presence of sulphated proteoglycans inside the construct, characteristic of cartilaginous tissue. Tartrate resistant alkaline phosphatase (TRAP) staining (leukocyte acid phosphatase kit, SigmaAldrich) was used to identify osteoclasts, while the presence of osteoblastic cells and osteoid structures was assessed by immunostaining for human bone sialoprotein (BSP, Immundiagnostik AG, www.immundiagnostik. com) (Minkin, 1982; Papadimitropoulos et al., 2011). The presence of donor-derived, human blood vessels was demonstrated by immunostaining with a biotin-conjugated antibody for human CD34 (Abcam, www.abcam.com), as previously described (Scherberich et al., 2007). All human cells in the explants were identified by chromogenic in situ hybridisation for the human-specific sequence ALU, using a biotin-conjugated DNA probe (ZytoVision, http:// zytovision.com), as previously described (Müller et al., 2010; Roy-Engel et al., 2001).

\section{Results}

The percentage of CFU-f in the SVF preparations from different human adipose tissue samples averaged $14.7 \pm 6.8 \%(n=4)$. The fractions of different SVF subpopulations were highly variable across different donors, as assessed by the large standard deviations in the percentage of positive cells for different typical surface markers (Fig. 1A) and in accordance with previous reports (Müller et al., 2009; Müller et al., 2010). Once embedded in a fibrin gel around ceramic granules, SVF cells were viable and homogenously distributed throughout the construct, as evidenced by MTT metabolic staining (Fig. $1 \mathrm{~B})$. The structure of the construct was investigated by H\&E staining of sections of decalcified samples (Fig. 1C and D). It allowed visualising the structural components of the constructs prior to implantation, including the fibrin 


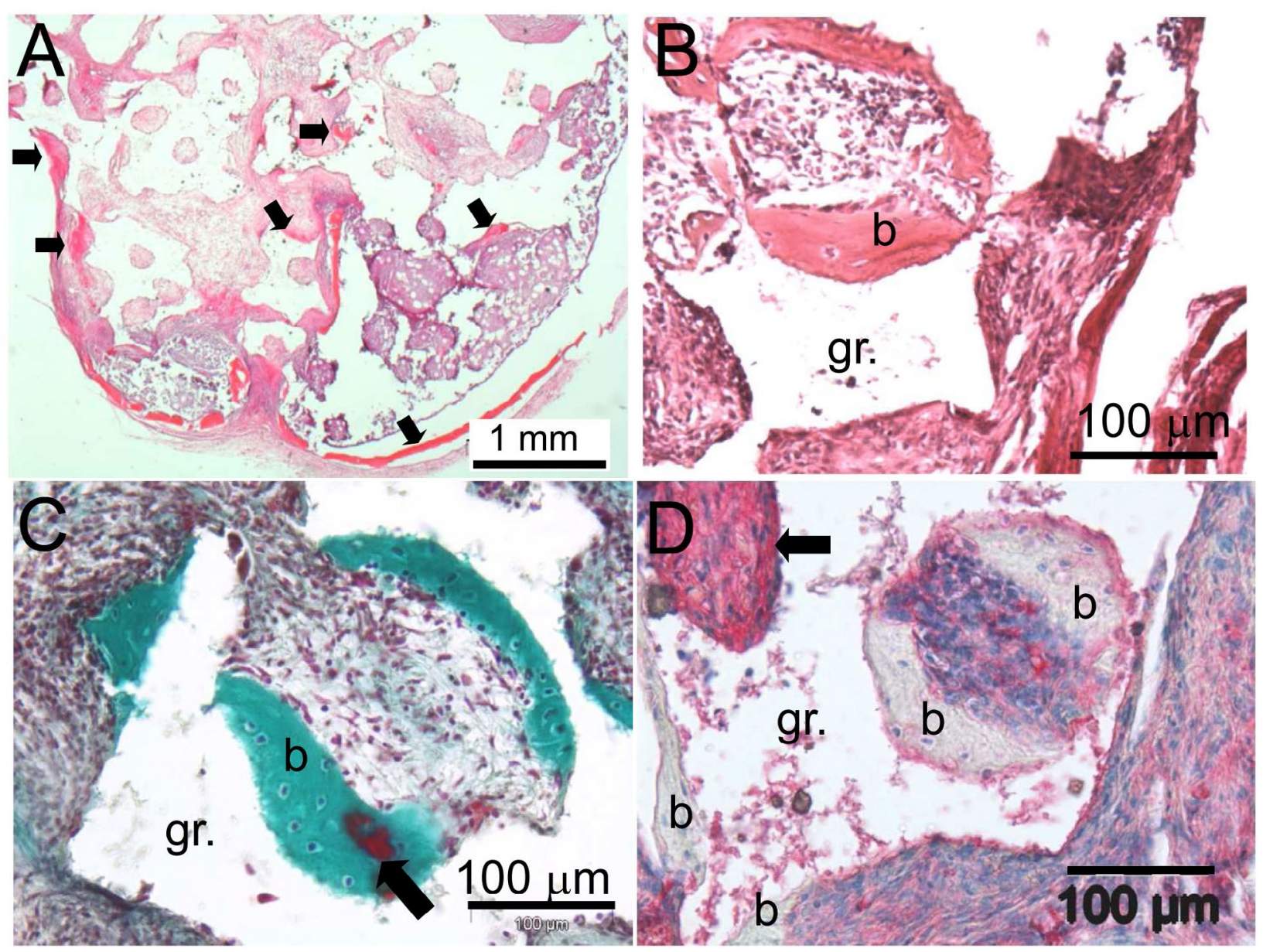

Fig. 3. Characterisation of newly-formed bone tissue. Histological analysis of sections of explanted, fixed and decalcified constructs seeded with $4 \times 10^{6} \mathrm{SVF}$ cells and rhBMP-2. (A) Haematoxylin/eosin. Arrows show newlyformed bone tissue both in the pores of granules and in a shell around the construct. (B) Higher magnification of the same sections showing compact bone matrix (b) and osteocytes embedded therein. (C) Masson's trichrome staining. The green dye stains dense collagenous matrix identifying bone tissue (b) in contact with the ceramic granules (gr.), with various stages of maturation, in particular zones with red staining characterising elastic proteins (arrows). (D) Immunostaining for BSP. The arrow indicates a zone with BSP-positive osteoblastic cells, where initial bone formation is on-going. Areas with mature bone tissue (b) do not contain osteoblastic cells.

gel (pink stain in Fig. 1C and D), the embedded cells (blue stain in Fig. 1D) and the porous ceramic granules (void spaces in decalcified samples, Fig. 1C).

In the absence of incorporated BMP-2 and independent of the initial cell density (1 or 4 million SVF cells per $100 \mathrm{~mm}^{3}$ construct), constructs explanted after subcutaneous implantation for 8 weeks in nude mice did not display evidence of frank bone tissue formation in any specimen, as assessed by H\&E staining (data not shown) and by fluorescence microscopy (Fig. 2, left column) of sections taken at different depths. These findings are in accordance with our previously published results (Müller et al., 2010). The addition of $250 \mathrm{ng}$ of rhBMP-2 inside the fibrin gel in conjunction with 4 million SVF cells, resulted in the formation of ectopic bone tissue, at a frequency ( 5 out of 7 donors) which was significantly different from the corresponding condition in the absence of rhBMP-2 ( 0 out of 7 donors) (Kruskal-Wallis with post-hoc Dunn's test). The use of a lower number of cells (1 million SVF cells) in the presence of rhBMP-2 also resulted in bone tissue formation, at a frequency (1 out of 3 donors) which was not significantly different from the one obtained with the higher cell number (Fig. 2).

Bone tissue formation was confirmed by H\&E staining both around the entire construct, in between the ceramic granules and within their pores (Fig. 3A, black arrows). Bone tissue displayed the typical features of an 'ossicle' structure, including a dense collagenous matrix with embedded osteocytes and a rim of osteoblasts in contact with the osteoid tissue (Fig. 3B). Masson's trichrome staining further qualified that the bone tissues was at various stages of maturation, with local spots of red stained regions, indicating the presence of elastic proteins and characteristic of a more mature bone tissue (Fig. 3C, black arrow). Neighbouring already developed bone ossicles, areas of pre-osteoid tissue were also identified by positive immunostaining for bone sialoprotein (Fig. 3D, black arrow). As a control group, implantation of ceramic-fibrinrhBMP-2 constructs without cells resulted in a merely fibrous tissue with no evidence of bone formation (data not shown). 


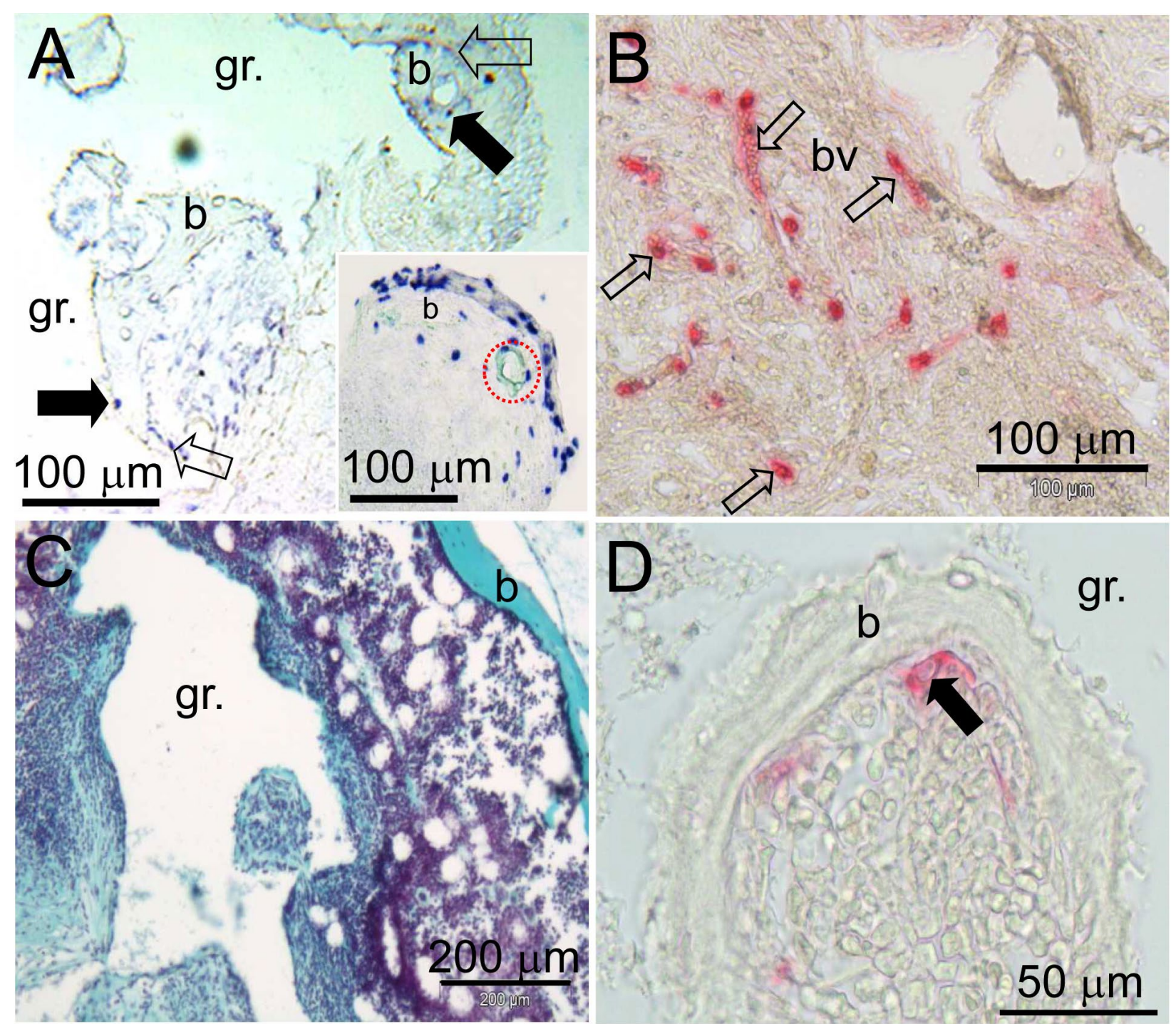

Fig. 4. Characterisation of the contribution of SVF cells to tissue formation. Histological analysis of sections of explanted, fixed and decalcified constructs seeded with $4 \times 10^{6}$ SVF cells and rhBMP-2. (A) In situ hybridisation for human-specific ALU sequences. Osteocytes (black arrows) and lining osteoblasts (open arrows) of human origin are identified by their nuclear ALU staining. Inset shows ALU nuclear staining of human endothelial cells at the level of human capillaries (red dashed line). (B) Immunostaining for human CD34 shows human blood vessels (bv, open arrows), filled with erythrocytes. (C) Safranin-O staining with no specific red staining indicative of sulphated proteoglycans and therefore of the generation of cartilaginous tissue inside the constructs. (D) TRAP staining showing the presence of multinucleated, osteoclastic cells in contact with newly formed bone (arrow). (b) indicates bone and (gr.) ceramic granules.

In order to study the contribution of implanted human SVF cells to the formation of tissue inside the construct, in situ hybridisation for human-specific ALU sequences was performed. Cells of human origin were identified both embedded within the bone matrix (putative osteocytes, black arrow in Fig. 4A) as well as at the bone matrix deposition front (putative osteoblasts, open arrow in Fig. 4A). ALU staining was also positive in the lumen of capillaries (putative endothelial cells, red circle in inset, Fig. 4A). The contribution of human vascular cells from the SVF to blood vessel formation was further confirmed by immunostaining for human CD34 (Fig. 4B, open arrows). The presence of erythrocytes in the lumen of the human capillary structures demonstrated functional connection with the host vasculature. Negative safranin-O staining indicated the absence of structures containing cartilage-specific glycosaminoglycans (Fig. 4C). TRAP staining identified the presence of multinucleated cells, likely of host origin, in contact with the newly formed bone (putative osteoclasts, arrow in Fig. 4D), suggesting an active remodelling process.

We next investigated the effect of rhBMP-2 on the percentage of osteoprogenitors recruited in vitro within the SVF cell population and the level of osteogenic induction of those osteoprogenitors in vitro. The CFU-o/CFU-f ratios, representing the fraction of clonogenic SVF cells displaying osteogenic properties, were higher in OM than in $\mathrm{CM}$, but were not affected by rhBMP- 2 at both tested concentrations 
A $\square 0 \mathrm{ng} / \mathrm{ml}$ BMP-2 $\square 50 \mathrm{ng} / \mathrm{ml} \mathrm{BMP-2} \square 500 \mathrm{ng} / \mathrm{ml} \mathrm{BMP-2}$

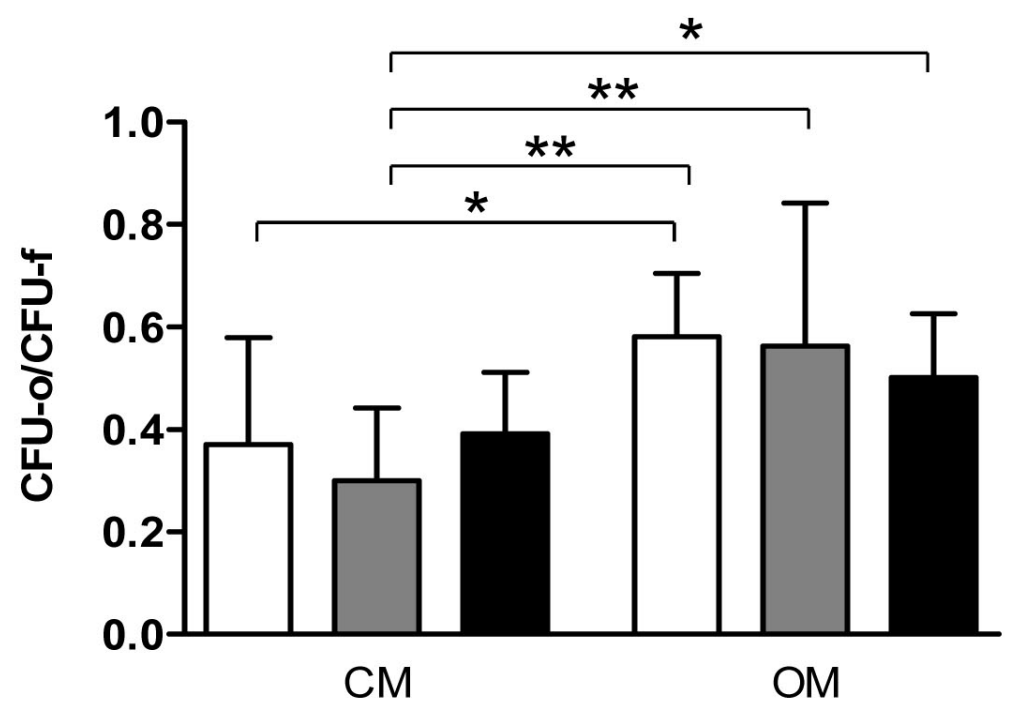

B

BSP

OP
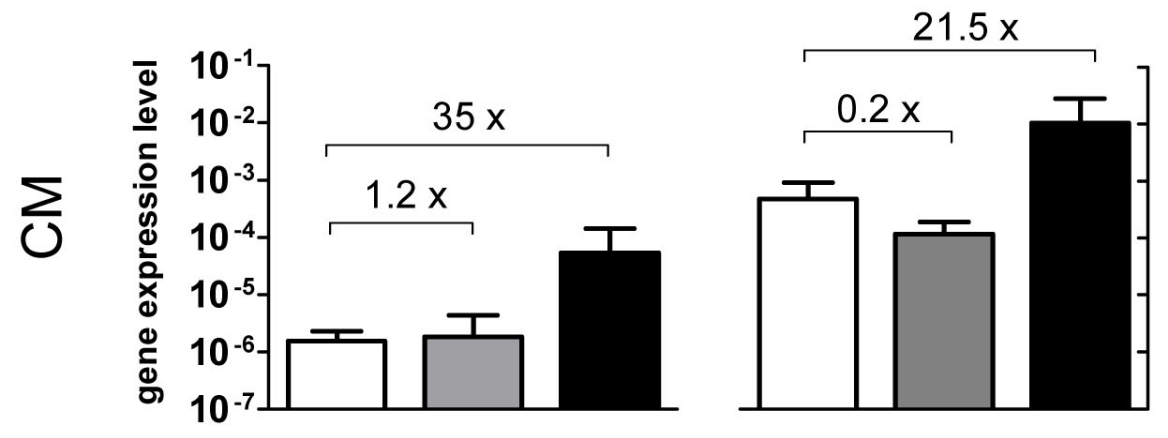

¿
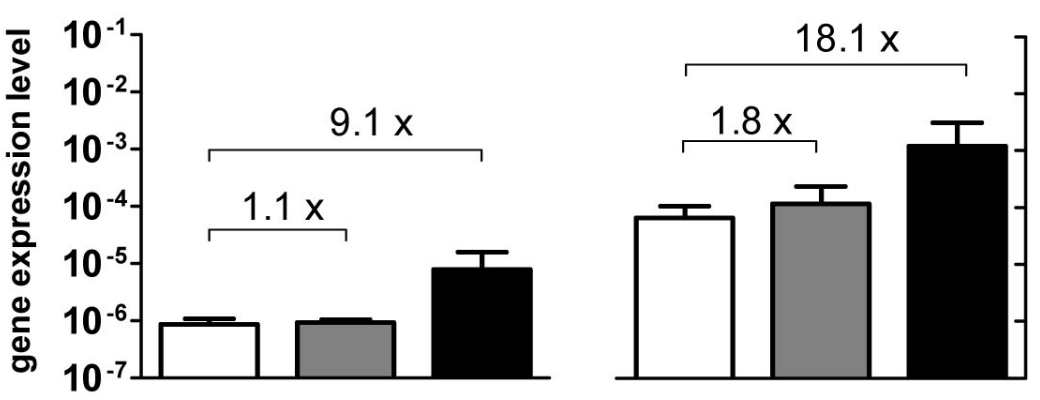

C
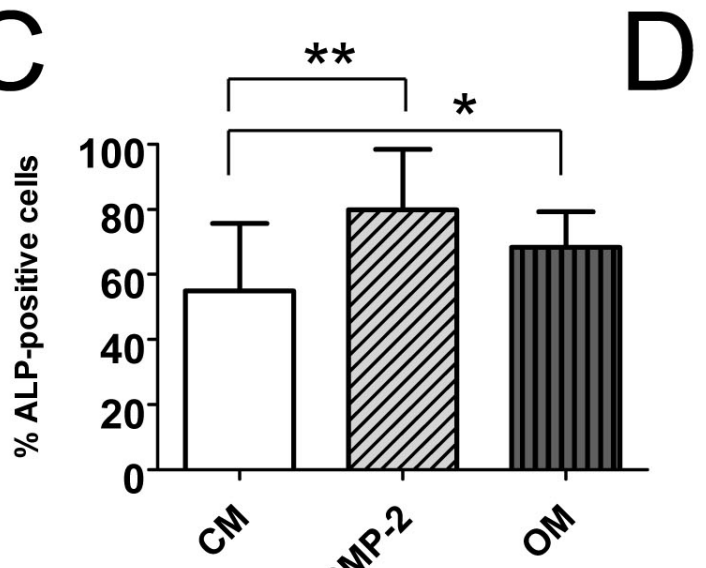

Fig 5. Legend on next page.

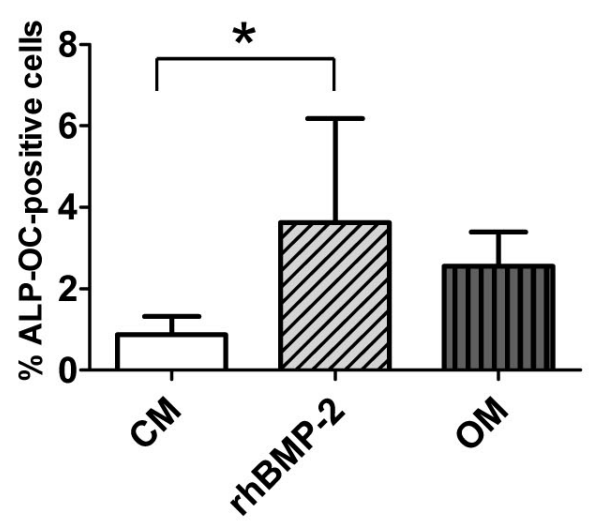


Fig. 5. (on previous page) In vitro effect of rhBMP-2 on human SVF cells. (A) Effect of 2 different doses of rhBMP-2 ( 50 and $500 \mathrm{ng} / \mathrm{mL}$ ) on the CFU-o/CFU-f ratio of human SVF cells cultured with either complete medium (CM) or osteoblastic induction medium (OM). Experiments were performed in triplicates with cells from $n=6$ independent donors. Average \pm s.d. is represented. (B) Effect of 2 different doses of rhBMP-2 (50 and $500 \mathrm{ng} / \mathrm{mL}$ ) on the expression levels of bone sialoprotein (BSP) or osteopontin (OP) mRNA. Results are represented as average \pm s.d. of the ratio between marker expression levels and expression levels of GAPDH. Experiments were performed in duplicate with cells from $n=3$ independent donors. (C and D) Effect of $500 \mathrm{ng} / \mathrm{mL}$ rhBMP-2 and OM on the percentage of cells expressing the osteoblastic markers alkaline phosphatase (ALP) (C) or ALP+osteocalcin (OC) (D). Experiments were performed with cells from $n=5$ independent donors. Average \pm s.d. is represented. * and ** indicate statistically significant differences ( $p<0.05$ and $p<0.01$, respectively) as tested by one-way ANOVA test followed by post-hoc Newman-Keuls tests.

(Fig. 5A). The level of osteogenic induction of SVF cells in vitro was assessed by the mRNA expression of osteoblastic markers, namely BSP and OP. The expression of these genes was not affected by medium supplementation with $50 \mathrm{ng} / \mathrm{mL}$ rhBMP-2, whereas it was consistently enhanced by the use of $500 \mathrm{ng} / \mathrm{mL}$ rhBMP-2, independently of the use of $\mathrm{CM}$ or OM (Fig. 5B). To confirm this trend in the effect of rhBMP-2 on the differentiation of the osteoprogenitors, the effect of $500 \mathrm{ng} / \mathrm{mL}$ rhBMP-2 on cells cultured with $\mathrm{CM}$ was tested by cytofluorimetry and compared to untreated cells (negative control) and cells cultured with OM (positive control). RhBMP-2 significantly increased the differentiation of osteoprogenitors (one-way ANOVA test followed by post-hoc Newman-Keuls tests), at levels similar to OM, based on the expression of ALP (Fig. 5C) and on cells co-expressing ALP and OC (Fig. 5D).

All results generated with own-produced or R\&Dproduced rhBMP-2, as specified in the Methods section, displayed consistent trends and no difference in efficiency at the same tested concentrations.

\section{Discussion}

This study validates an intraoperative manufacturing concept for the generation of grafts with osteogenic/ vasculogenic potential derived from human adipose tissue. The formation of bone tissue was shown to require the delivery of a low dose of rhBMP-2, which could not induce ectopic ossification by itself. The reproducibility of bone tissue formation might well be improved by increasing the density of implanted SVF cells, which not only supported but directly contributed to bone tissue formation. The in vitro results suggest that the mode of action of rhBMP-2 did not involve an increase in the percentage of SVF cells recruited to the osteogenic lineage, but rather a stimulation of the osteoblastic differentiation of the committed progenitors.

Previous reports demonstrated that SVF cells, freshly isolated from adipose tissue and immediately implanted, can enhance bone healing in orthotopic experimental animal models (reviewed in Scherberich et al., 2010). Autologous SVF cells have also been used in an intraoperative approach in a few clinical cases, demonstrating safety and a favourable clinical outcome (Lendeckel et al., 2004; Pak, 2011). However, in all these studies, the direct contribution of the implanted cells to bone formation was not addressed and therefore the intrinsic osteogenic capacity of freshly harvested SVF cells had not yet been demonstrated. The experimental setup used in the present work, namely an ectopic implantation site in a nude mouse model, allowed us to investigate the fate and mode of action of the implanted human SVF cells and therefore to conclude that SVF cells can directly form bone tissue, but only when stimulated in situ by rhBMP-2.

The induction of bone formation by BMPs in vivo was described for the first time in 1965 (Urist, 1965). Numerous in vitro and in vivo studies have later demonstrated enhanced bone repair by rhBMP-2, which is now FDA-approved in spinal, trauma and maxillo-facial surgery (Govender et al., 2002; Hsu and Wang, 2008; Jones et al., 2006; Smith et al., 2008). The clinical use of rhBMP-2 is based on the principle of induction of osteogenesis by resident precursor cells and requires very high and non-physiological doses, which have been reported to be associated with aberrant bone formation (Deutsch, 2010), neurotoxicity (Smith et al., 2008) or cancer development (Carragee et al., 2011). As compared to commercially available products, which contain $1.5 \mathrm{mg} / \mathrm{mL}$ rhBMP-2, the concentration used in the present study $(2.5 \mu \mathrm{g} / \mathrm{mL}$ construct $)$ was about three orders of magnitude lower. The dose, which to the best of our knowledge is lower than the minimal one ever reported for stimulation of adipose-derived cells in vivo (Jeon et al., 2008), was not intrinsically associated with osteoinductivity and supported bone formation only by acting in concert with the implanted cells. Moreover, it cannot be excluded that the combination of implanted human cells and rhBMP-2 could have recruited resident cells from the host which may have directly contributed to bone formation in conjunction with implanted boneforming cells.

The actual osteogenic responsiveness of mesenchymal stromal cells to BMPs, in particular for osteoprogenitors derived from adipose and bone marrow tissues, is still controversial. Indeed, while some groups reported no significant difference of bone formation after addition of rhBMP-2 (Chou et al., 2011; Diefenderfer et al., 2003; Osyczka et al., 2004; Zuk et al., 2011) or transfection with hBMP-2 gene (Peterson et al., 2005), some others reported induction of bone repair by BMP-2 stimulation of adiposederived osteoprogenitors (Jeon et al., 2008; Lee et al., 2010). This discrepancy may result from factors such as the high inter-donor variability, the variety of animal models and experimental settings, as well as the doses of rhBMP-2 
used (Zara et al., 2011). Also age and sex of the donor seem to influence the osteogenic potential of osteoprogenitors (van Harmelen et al., 2003; Zhu et al., 2009), as well as their responsiveness to rhBMP-2 (Kim et al., 2008). Our in vitro results indicate that rhBMP-2 specifically stimulated the osteoblastic differentiation of SVF cells. No effect of rhBMP-2 on adipose-derived cell differentiation was seen with $50 \mathrm{ng} / \mathrm{mL}$, confirming a previous report (Zuk et al., 2011) showing no effect at doses ranging 10-100 ng/mL. We however demonstrated in this study, both at the gene expression and protein expression level, that a $500 \mathrm{ng} /$ $\mathrm{mL}$ concentration stimulated osteoblastic differentiation of adipose-derived cells. For the in vivo study, we used a cumulative dose of rhBMP-2 $\left(2.5 \mu \mathrm{g} / \mathrm{cm}^{3}\right.$ construct $)$ which was in the same range as the total amount of rhBMP-2 supplemented in vitro for the culture duration of 2 weeks $(1.5 \mu \mathrm{g})$. However, considering the different release profiles (i.e., 3 repetitive doses for monolayer culture in vitro, versus burst release from the gel in vivo) and the different cell mixes (i.e., pure ASC in vitro, versus SVF cells containing mesenchymal, endothelial and haematopoietic populations in vivo), the effective concentration delivered to cells in the two models cannot be directly compared.

Both bacteria- and mammalian cell-derived rhBMP-2 were used in parallel in this study and demonstrated that the lack of response at $50 \mathrm{ng} / \mathrm{mL}$ was not due to the origin or glycosylation status of rhBMP-2. This confirmed our recent results showing that bacterial rhBMP-2 displays similar bioactivity for in vitro osteoblastic differentiation as compared to the medical grade, $\mathrm{CHO}$ cell-derived rhBMP-2 from Medtronic (Hanseler et al., 2012). Interestingly, there have been promising results in enhancing bone formation by adipose tissue cells also by addition of vitamin D3 (Song et al., 2011), alendronate (Wang et al., 2010) or platelet-rich plasma (Liu et al., 2008). Whether or not addition of these substrates, alone or in combination with rhBMP-2, could lead to a more reliable bone formation in the proposed setup will also have to be investigated. Finally, although rhBMP-2 was previously reported to have the potential to stimulate angiogenesis (Deckers et al., 2002; Peng et al., 2005), in our study the presence of human endothelial cells (positively stained for ALU sequences and for human CD34) in graft vascularisation did not appear to be increased in the presence of rhBMP-2 (data not shown).

\section{Conclusion}

This study reinforces the feasibility of an intraoperative use of autologous SVF cells for bone regeneration. The approach requires only one surgical procedure, similar to autologous bone grafting but clearly with reduced morbidity at the donor site. Moreover, it does not require extensive processing and culture of the isolated cells, thereby also reducing the costs and regulatory burdens otherwise associated with advanced cellular therapies. The use of low doses of rhBMP-2 was essential in the ectopic model to drive osteoblastic differentiation of SVF progenitors, but could be bypassed upon implantation at an orthotopic site, in the context of a bone environment where such physiological amounts of BMPs are likely already present. Recent work on the established interaction between the immune system and osteoprogenitor cell function (Liu et al., 2011) also prompts for further studies in immunocompetent models with a proper onset of inflammatory processes. However, the introduction of alternative in vivo models requires the use of animal as opposed to human adipose-derived cells, which are known to have markedly different biological properties and osteogenic potential (Levi et al., 2011) and thus would limit the potential clinical relevance of the generated findings. In this regard, one of the most compelling challenges in the routine clinical implementation of this approach is related to the large variability in phenotype and bone forming capacity of human adipose-derived cells from different donors (Scherberich et al., 2007). Therefore, one additional effort will have to involve the identification of reliable quality control/potency markers of the implanted cells, in order to ultimately define the number of cells with a specific phenotype which should be introduced per unit of construct volume to ensure reproducible bone formation.

\section{Acknowledgments}

We are grateful to ApaTech GmbH (Germany) and to Dr. Andreas Goessl (Baxter Biosurgery, Austria) for the generous supply of the Actifuse $\mathrm{ABX}$ microgranules and the Tisseel ${ }^{\circledR}$ fibrin glue, respectively, used in the present study. We thank Benjamin Pippenger for his help with the cytofluorimetric analysis of osteoblastic differentiation. We acknowledge financial support by the Swiss National Science Foundation (Grant 310030-120432), to A.S. We wish to confirm that there are no known conflicts of interest associated with this publication and there has been no significant financial support for this work that could have influenced its outcome.

\section{References}

Aslan H, Zilberman Y, Kandel L, Liebergall M, Oskouian RJ, Gazit D, Gazit Z (2006) Osteogenic differentiation of noncultured immunoisolated bone marrow-derived CD105+ cells. Stem Cells 24: 1728-1737.

Baksh D, Davies JE, Zandstra PW (2003) Adult human bone marrow-derived mesenchymal progenitor cells are capable of adhesion-independent survival and expansion. Exp Hematol 31: 723-732.

Banfi A, Muraglia A, Dozin B, Mastrogiacomo M, Cancedda R, Quarto R (2000) Proliferation kinetics and differentiation potential of ex vivo expanded human bone marrow stromal cells: Implications for their use in cell therapy. Exp Hematol 28: 707-715.

Barbero A, Ploegert S, Heberer M, Martin I (2003) Plasticity of clonal populations of dedifferentiated adult human articular chondrocytes. Arthritis Rheum 48: 1315 1325 .

Bensaid W, Triffitt JT, Blanchat C, Oudina K, Sedel L, Petite H (2003) A biodegradable fibrin scaffold for mesenchymal stem cell transplantation. Biomaterials 24: 2497-2502. 
Berner A, Reichert JC, Müller MB, Zellner J, Pfeifer C, Dienstknecht T, Nerlich M, Sommerville S, Dickinson IC, Schutz MA, Fuchtmeier B (2012) Treatment of long bone defects and non-unions: from research to clinical practice. Cell Tissue Res 347: 501-519.

Braccini A, Wendt D, Jaquiery C, Jakob M, Heberer M, Kenins L, Wodnar-Filipowicz A, Quarto R, Martin I (2005) Three-dimensional perfusion culture of human bone marrow cells and generation of osteoinductive grafts. Stem Cells 23: 1066-1072.

Carragee EJ, Hurwitz EL, Weiner BK (2011) A critical review of recombinant human bone morphogenetic protein-2 trials in spinal surgery: emerging safety concerns and lessons learned. Spine J 11: 471-491.

Chen D, Zhao M, Mundy GR (2004) Bone morphogenetic proteins. Growth Factors 22: 233-241.

Chou YF, Zuk PA, Chang TL, Benhaim P, Wu BM (2011) Adipose-derived stem cells and BMP2: Part 1. BMP2-treated adipose-derived stem cells do not improve repair of segmental femoral defects. Connect Tissue Res 52: 109-118.

Cox G, McGonagle D, Boxall SA, Buckley CT, Jones E, Giannoudis PV (2011) The use of the reamer-irrigatoraspirator to harvest mesenchymal stem cells. J Bone Joint Surg Br 93: 517-524.

Cuomo AV, Virk M, Petrigliano F, Morgan EF, Lieberman JR (2009) Mesenchymal stem cell concentration and bone repair: potential pitfalls from bench to bedside. J Bone Joint Surg Am 91: 1073-1083.

De LW, Jr., Einhorn TA, Koval K, McKee M, Smith W, Sanders R, Watson T (2007) Bone grafts and bone graft substitutes in orthopaedic trauma surgery. A critical analysis. J Bone Joint Surg Am 89: 649-658.

Deckers MM, van Bezooijen RL, van der HG, Hoogendam J, van Der BC, Papapoulos SE, Lowik CW (2002) Bone morphogenetic proteins stimulate angiogenesis through osteoblast-derived vascular endothelial growth factor A. Endocrinology 143: 15451553.

Deutsch H (2010) High-dose bone morphogenetic protein-induced ectopic abdomen bone growth. Spine J 10: e1-e4.

Diefenderfer DL, Osyczka AM, Reilly GC, Leboy PS (2003) BMP responsiveness in human mesenchymal stem cells. Connect Tissue Res 44 Suppl 1: 305-311.

Evans CH, Palmer GD, Pascher A, Porter R, Kwong FN, Gouze E, Gouze JN, Liu F, Steinert A, Betz O, Betz V, Vrahas M, Ghivizzani SC (2007) Facilitated endogenous repair: making tissue engineering simple, practical, and economical. Tissue Eng 13: 1987-1993.

Frank O, Heim M, Jakob M, Barbero A, Schafer D, Bendik I, Dick W, Heberer M, Martin I (2002) Real-time quantitative RT-PCR analysis of human bone marrow stromal cells during osteogenic differentiation in vitro. $\mathrm{J}$ Cell Biochem 85: 737-746.

Fraser JK, Wulur I, Alfonso Z, Hedrick MH (2006) Fat tissue: an underappreciated source of stem cells for biotechnology. Trends Biotechnol 24: 150-154.

Friedenstein AJ, Chailakhjan RK, Lalykina KS (1970) The development of fibroblast colonies in monolayer cultures of guinea-pig bone marrow and spleen cells. Cell Tissue Kinet 3: 393-403.

Fujimura K, Bessho K, Kusumoto K, Ogawa Y, Iizuka $\mathrm{T}$ (1995) Experimental studies on bone inducing activity of composites of atelopeptide type I collagen as a carrier for ectopic osteoinduction by rhBMP-2. Biochem Biophys Res Commun 208: 316-322.

Govender S, Csimma C, Genant HK, Valentin-Opran A, Amit Y, Arbel R, Aro H, Atar D, Bishay M, Borner MG, Chiron P, Choong P, Cinats J, Courtenay B, Feibel R, Geulette B, Gravel C, Haas N, Raschke M, Hammacher E, van d, V, Hardy P, Holt M, Josten C, Ketterl RL, Lindeque B, Lob G, Mathevon H, McCoy G, Marsh D, Miller R, Munting E, Oevre S, Nordsletten L, Patel A, Pohl A, Rennie W, Reynders P, Rommens PM, Rondia J, Rossouw WC, Daneel PJ, Ruff S, Ruter A, Santavirta S, Schildhauer TA, Gekle C, Schnettler R, Segal D, Seiler H, Snowdowne RB, Stapert J, Taglang G, Verdonk R, Vogels L, Weckbach A, Wentzensen A, Wisniewski T (2002) Recombinant human bone morphogenetic protein-2 for treatment of open tibial fractures: a prospective, controlled, randomised study of four hundred and fifty patients. J Bone Joint Surg Am 84A: 2123-2134.

Gronthos S, Franklin DM, Leddy HA, Robey PG, Storms RW, Gimble JM (2001) Surface protein characterization of human adipose tissue-derived stromal cells. J Cell Physiol 189: 54-63.

Güven S, Mehrkens A, Saxer F, Schaefer DJ, Martinetti R, Martin I, Scherberich A (2011) Engineering of large osteogenic grafts with rapid engraftment capacity using mesenchymal and endothelial progenitors from human adipose tissue. Biomaterials 32: 5801-5809.

Hanseler P, Jung UW, Jung RE, Choi KH, Cho KS, Hammerle CH, Weber FE (2012) Analysis of hydrolyzable polyethylene glycol hydrogels and deproteinized bone mineral as delivery systems for glycosylated and nonglycosylated bone morphogenetic protein-2. Acta Biomater 8: 116-123.

Helder MN, Knippenberg M, Klein-Nulend J, Wuisman PI (2007) Stem cells from adipose tissue allow challenging new concepts for regenerative medicine. Tissue Eng 13: 1799-1808.

Hsu WK, Wang JC (2008) The use of bone morphogenetic protein in spine fusion. Spine J 8: 419-425.

Jeon O, Rhie JW, Kwon IK, Kim JH, Kim BS, Lee SH (2008) In vivo bone formation following transplantation of human adipose-derived stromal cells that are not differentiated osteogenically. Tissue Eng Part A 14: 1285 1294.

Jones AL, Bucholz RW, Bosse MJ, Mirza SK, Lyon TR, Webb LX, Pollak AN, Golden JD, Valentin-Opran A (2006) Recombinant human BMP-2 and allograft compared with autogenous bone graft for reconstruction of diaphyseal tibial fractures with cortical defects. A randomized, controlled trial. J Bone Joint Surg Am 88: 1431-1441.

Kim IS, Song YM, Cho TH, Park YD, Lee KB, Noh I, Weber F, Hwang SJ (2008) In vitro response of primary human bone marrow stromal cells to recombinant human bone morphogenic protein-2 in the early and late stages of osteoblast differentiation. Dev Growth Differ 50: 553-564. 
Lee SJ, Kang SW, Do HJ, Han I, Shin DA, Kim JH, Lee SH (2010) Enhancement of bone regeneration by gene delivery of BMP2/Runx2 bicistronic vector into adiposederived stromal cells. Biomaterials 31: 5652-5659.

Lendeckel S, Jodicke A, Christophis P, Heidinger K, Wolff J, Fraser JK, Hedrick MH, Berthold L, Howaldt HP (2004) Autologous stem cells (adipose) and fibrin glue used to treat widespread traumatic calvarial defects: case report. J Craniomaxillofac Surg 32: 370-373.

Levi B, Nelson ER, Brown K, James AW, Xu D, Dunlevie R, Wu JC, Lee M, Wu B, Commons GW, Vistnes D, Longaker MT (2011) Differences in osteogenic differentiation of adipose-derived stromal cells from murine, canine, and human sources in vitro and in vivo. Plast Reconstr Surg 128: 373-386.

Liu Y, Zhou Y, Feng H, Ma GE, Ni Y (2008) Injectable tissue-engineered bone composed of human adiposederived stromal cells and platelet-rich plasma. Biomaterials 29: 3338-3345.

Liu Y, Wang L, Kikuiri T, Akiyama K, Chen C, Xu X, Yang R, Chen W, Wang S, Shi S (2011) Mesenchymal stem cell-based tissue regeneration is governed by recipient $\mathrm{T}$ lymphocytes via IFN-gamma and TNF-alpha. Nat Med 17: 1594-1601.

Martin I, Smith T, Wendt D (2009) Bioreactor-based roadmap for the translation of tissue engineering strategies into clinical products. Trends Biotechnol 27: 495-502.

Meijer GJ, de Bruijn JD, Koole R, van Blitterswijk CA (2007) Cell-based bone tissue engineering. PLoS Med 4: e9.

Minkin C (1982) Bone acid phosphatase: tartrateresistant acid phosphatase as a marker of osteoclast function. Calcif Tissue Int 34: 285-290.

Müller AM, Davenport M, Verrier S, Droeser R, Alini M, Bocelli-Tyndall C, Schaefer DJ, Martin I, Scherberich A (2009) Platelet lysate as a serum substitute for 2D static and $3 \mathrm{D}$ perfusion culture of stromal vascular fraction cells from human adipose tissue. Tissue Eng Part A 15: 869-875.

Müller AM, Mehrkens A, Schafer DJ, Jaquiery C, Güven S, Lehmicke M, Martinetti R, Farhadi I, Jakob M, Scherberich A, Martin I (2010) Towards an intraoperative engineering of osteogenic and vasculogenic grafts from the stromal vascular fraction of human adipose tissue. Eur Cell Mater 19: 127-135.

Osyczka AM, Diefenderfer DL, Bhargave G, Leboy PS (2004) Different effects of BMP-2 on marrow stromal cells from human and rat bone. Cells Tissues Organs 176: 109-119.

Pak J (2011) Regeneration of human bones in hip osteonecrosis and human cartilage in knee osteoarthritis with autologous adipose-tissue-derived stem cells: a case series. J Med Case Reports 5: 296.

Papadimitropoulos A, Scherberich A, Güven S, Theilgaard N, Crooijmans HJ, Santini F, Scheffler K, Zallone A, Martin I (2011) A 3D in vitro bone organ model using human progenitor cells. Eur Cell Mater 21: 445-458.

Peng H, Usas A, Olshanski A, Ho AM, Gearhart B, Cooper GM, Huard J (2005) VEGF improves, whereas sFlt1 inhibits, BMP2-induced bone formation and bone healing through modulation of angiogenesis. J Bone Miner Res 20: 2017-2027.
Peterson B, Zhang J, Iglesias R, Kabo M, Hedrick M, Benhaim P, Lieberman JR (2005) Healing of critically sized femoral defects, using genetically modified mesenchymal stem cells from human adipose tissue. Tissue Eng 11: 120 129.

Roy-Engel AM, Carroll ML, Vogel E, Garber RK, Nguyen SV, Salem AH, Batzer MA, Deininger PL (2001) Alu insertion polymorphisms for the study of human genomic diversity. Genetics 159: 279-290.

Saxer F, Scherberich A, Martin I (2010) Innovative cell-based approaches for bone regeneration. J Osteol Biomater 1: 5-9.

Scherberich A, Galli R, Jaquiery C, Farhadi J, Martin I (2007) Three-dimensional perfusion culture of human adipose tissue-derived endothelial and osteoblastic progenitors generates osteogenic constructs with intrinsic vascularization capacity. Stem Cells 25: 1823-1829.

Scherberich A, Müller AM, Schafer DJ, Banfi A, Martin I (2010) Adipose tissue-derived progenitors for engineering osteogenic and vasculogenic grafts. J Cell Physiol 225: 348-353.

Smith DM, Cooper GM, Mooney MP, Marra KG, Losee JE (2008) Bone morphogenetic protein 2 therapy for craniofacial surgery. J Craniofac Surg 19: 1244-1259.

Song I, Kim BS, Kim CS, Im GI (2011) Effects of BMP-2 and vitamin D3 on the osteogenic differentiation of adipose stem cells. Biochem Biophys Res Commun 408: 126-131.

Stafford PR, Norris BL (2010) Reamer-irrigatoraspirator bone graft and bi Masquelet technique for segmental bone defect nonunions: a review of 25 cases. Injury 41 Suppl 2: S72-S77.

Urist MR (1965) Bone: formation by autoinduction. Science 150: 893-899.

van Harmelen, V, Skurk T, Rohrig K, Lee YM, Halbleib M, prath-Husmann I, Hauner H (2003) Effect of BMI and age on adipose tissue cellularity and differentiation capacity in women. Int J Obes Relat Metab Disord 27: 889-895.

Vergroesen PP, Kroeze RJ, Helder MN, Smit TH (2011) The use of poly(L-lactide-co-caprolactone) as a scaffold for adipose stem cells in bone tissue engineering: application in a spinal fusion model. Macromol Biosci 11: 722-730.

Wang CZ, Chen SM, Chen CH, Wang CK, Wang GJ, Chang JK, Ho ML (2010) The effect of the local delivery of alendronate on human adipose-derived stem cell-based bone regeneration. Biomaterials 31: 8674-8683.

Weber FE, Eyrich G, Gratz KW, Maly FE, Sailer HF (2002) Slow and continuous application of human recombinant bone morphogenetic protein via biodegradable poly(lactide-co-glycolide) foamspheres. Int J Oral Maxillofac Surg 31: 60-65.

Zara JN, Siu RK, Zhang X, Shen J, Ngo R, Lee M, Li W, Chiang M, Chung J, Kwak J, Wu BM, Ting K, Soo C (2011) High doses of bone morphogenetic protein 2 induce structurally abnormal bone and inflammation in vivo. Tissue Eng Part A 17: 1389-1399.

Zhu M, Kohan E, Bradley J, Hedrick M, Benhaim P, Zuk P (2009) The effect of age on osteogenic, adipogenic and proliferative potential of female adipose-derived stem cells. J Tissue Eng Regen Med 3: 290-301. 
Zuk P, Chou YF, Mussano F, Benhaim P, Wu BM (2011) Adipose-derived stem cells and BMP2: Part 2. BMP2 may not influence the osteogenic fate of human adipose-derived stem cells. Connect Tissue Res 52: 119-132.

\section{Discussion with Reviewers}

Reviewer I: These interesting findings need to be validated in bone defect models. In particular, the authors suggest that BMP-2 may not be required in orthotopic sites which could provide a favourable environment to promote osteoblastic maturation of MSCs. Likewise, we could assume that BMP-2 alone without cells in an environment rich in osteoblast progenitors may be sufficient to promote bone repair. These challenges could be addressed in bone lesions models in nude rats, which would allow the use of human MSCs.

Authors: This is a very good suggestion from the reviewer. We have indeed already initiated such a study in a femoral defect in nude rat to address this question. The study is currently in progress but preliminary data suggest that human SVF cells can generate bone tissue in the absence of BMP-2 in such a model. Comparison of the bone repair with SVF cells to acellular constructs loaded with only BMP-2 is also within the next series of experiments to be performed. 